Wacana Vol. 16 No. 1 (2015): 27-41

\title{
Causative constructions in Woirata, Kisar Island (Southwest Maluku, Indonesia)
}

\author{
NAZARUDIN
}

\begin{abstract}
${ }^{1}$
Woirata (or Oirata, see Van Engelenhoven in this volume) is closely related to Fataluku (Timor-Leste) and belongs to the Timor-Leste subgroup of the Timor-Alor-Pantar language family (TAP) together with Makalero and Makasai (Schapper, Huber, and Van Engelenhoven 2012). It has about 1,566 speakers. Taber (1993) suggests that there are 24 languages in Southwest Maluku of which 23 are Austronesian; Woirata is the only non-Austronesian language in the area. It is interesting to research in how far Woirata has been influenced by Austronesian languages. Because the Woirata and other people who live on Kisar Island, like the Meher, are using Melayu Tenggara Jauh (MTJ) as their lingua franca, one may expect deep language contact between Woirata and MTJ. This multilingual situation suggests a contact induced language change of Woirata, imposed by MTJ. This contribution aims to describe the causative constructions in Woirata and compare them with the counterpart constructions in MTJ and Meher.
\end{abstract}

KEYWORDS

Language use, Woirata, causative construction, language contact.

1 Some of the data in this article were collected in a research project from 2012 to 2014 that was funded by Pusat Penelitian Kebudayaan dan Kemasyarakatan, Lembaga Ilmu Pengetahuan Indonesia (P2KK LIPI).

NAZARUDIN is a lecturer at the Linguistics Department, Faculty of Humanities Universitas Indonesia. He took his Master degree in Linguistics at Inha University, Incheon, South Korea 2010. He is currently doing his PhD in Linguistics at Leiden University Centre for Linguistics (LUCL) in the research project "A descriptive grammar of Woirata; An endangered language on Kisar Island, Southwest Maluku, Indonesia" under the supervision of Prof. Maarten Mous and Dr. Aone van Engelenhoven. From 2012 - 2014 he participated in a research project by Pusat Penelitian Kebudayaan dan Kemasyarakatan Lembaga Ilmu Pengetahuan Indonesia (P2KK LIPI) on endangered Non-Austronesian languages. His main research interests are descriptive linguistics, language documentation, linguistic anthropology, and corpus linguistics. Nazarudin may be contacted at: n.nazarudin@hum.leidenuniv.nl. 


\section{BACKGROUND ${ }^{2}$}

Today, most linguists agree that there are about 7,000 languages spoken across the world and almost half of these may no longer be in existence after a few more generations. The largest language distribution is in Asia, about 33\% from all the languages in the world (Grenoble 2011: 28). In Indonesia, there are about 742 languages (Lewis et al. 2014). Languages in Indonesia fall into two main families, Austronesian languages and Papuan or non-Austronesian languages.

Woirata (Kisar Island, Southwest Maluku, see Maps 1 and 2) is closely related to Fataluku (Timor-Leste) and belongs to the East Timor subgroup of the Timor-Alor-Pantar language family (TAP) together with Makalero and Makasai (Schapper, Huber, and Van Engelenhoven 2012). It has about 1,566 speakers. From a historical point of view it features many characteristics which corroborate that Woirata is linked through Proto Timor-Alor-Pantar to the Trans New Guinea Phylum, for example, the alveolar retroflex [ $t]$ and the glottal stop [?] in its phonology, respectively transcribed here as $\mathrm{d}$ and ', the singular-plural distinction in its morphology and its clause-final negation. The other main language spoken on Kisar Island is Meher with more than 10,000 speakers. Apart from on Kisar, Meher is also found on Romang Island and in Kisar settlements throughout Indonesia, as for example on Wetar Island and in Ambon, Kupang and Jakarta. This language belongs to the LuangicKisaric branch of the Central Malayo-Polynesian branch of Austronesian (Van Engelenhoven 2009a).

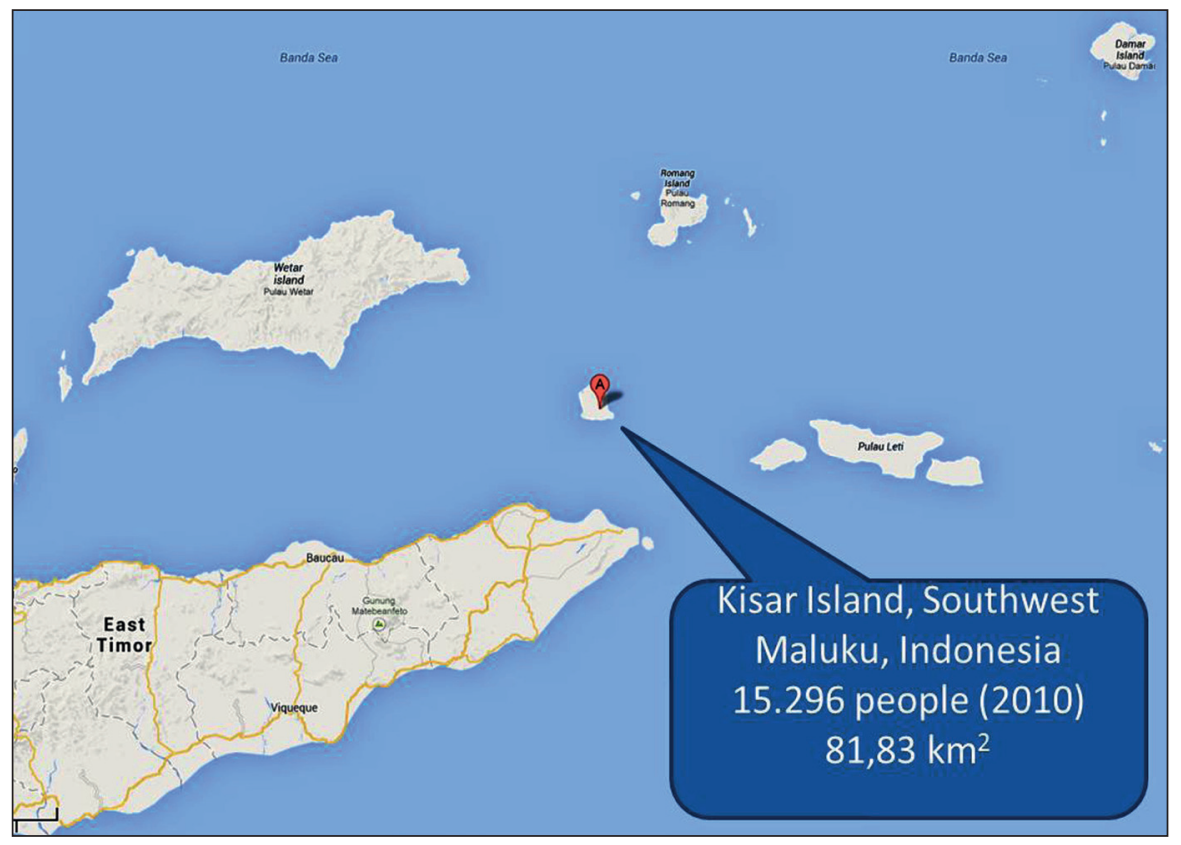

Map 1. Southwest Maluku, Indonesia.

2 This article is dedicated to two of my inspirators in linguistics, Prof. Dr. Harimurti Kridalaksana and Prof. Dr. Hein Steinhauer. 


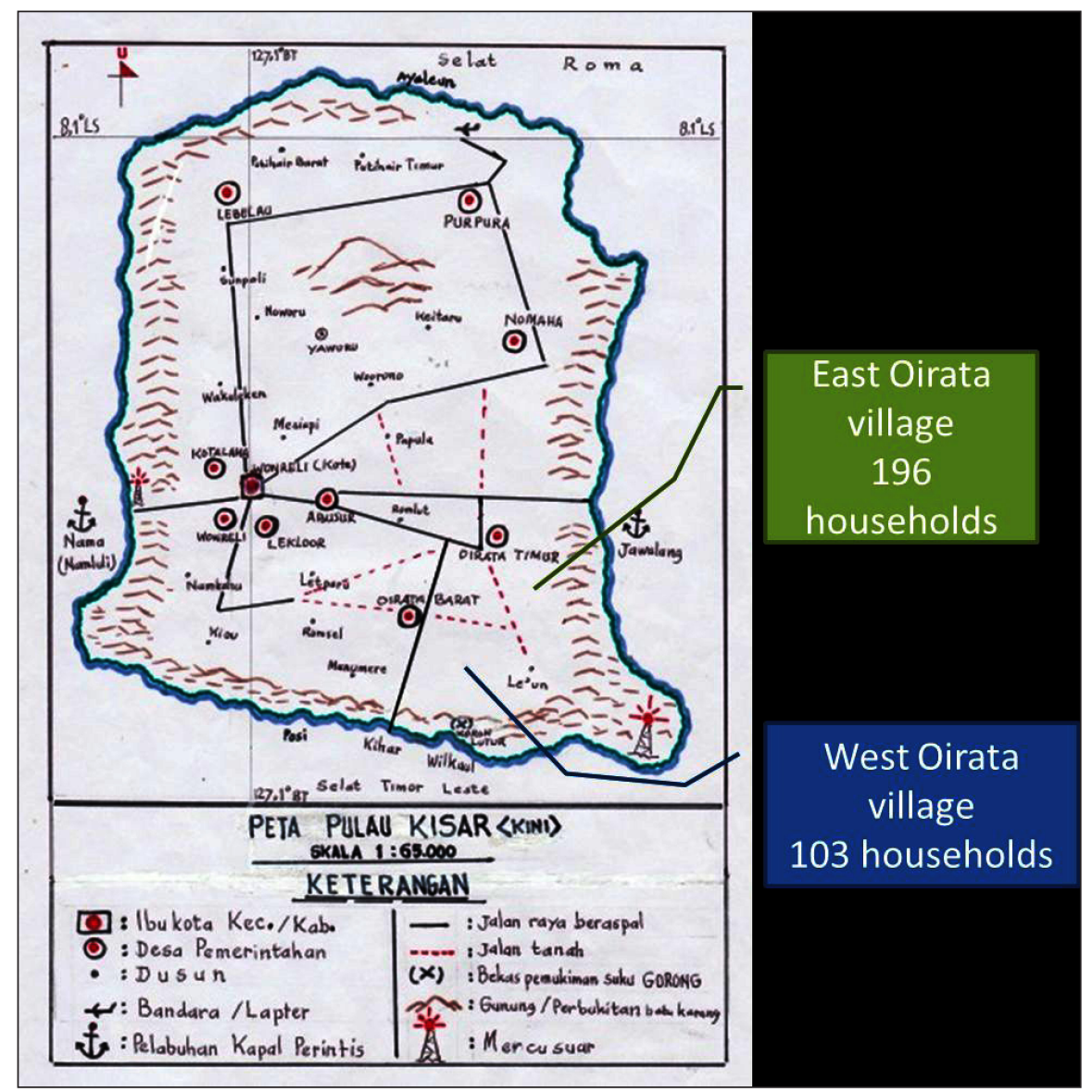

Map 2. Kisar Island.

Taber (1993) suggests there are 24 languages in Southwest Maluku, of which 23 are Austronesian; Woirata is the only Non-Austronesian language in the area. As such, it is interesting to research see how far Woirata is influenced by Austronesian languages. Van Engelenhoven's (2010a) analysis of the Makuva language in Lautem District (Timor-Leste) that is closely related to the Luangic-Kisaric languages in Southwest Maluku shows a contact scenario in which a Luangic-Kisaric (Austronesian) type of grammar is strongly influenced by the (non-Austronesian) grammar of the Fataluku majority language. The Woirata case displays the opposite scenario in which a non- Austronesian language (Woirata) is completely surrounded by an Austronesian language (Meher). Faust (2006) points out that at least the sung parts in De Josselin de Jong's (1937) Woirata text are not in genuine Woirata, but rather in the Austronesian 'Sung Language'. This is a reasonable assumption, since Woirata does not have any traditional songs in their language. They sing in Meher on every occasion. The impact of Meher on Woirata is high and can easily be seen in the many Meher borrowings in the Woirata lexicon. For example in Woirata there are two words for 'house', le and natara. The first word le is an original Woirata word, whereas the second word natara is borrowed from 
Old Meher natar (nowadays nakar).

Preliminary fieldwork suggests language uses of Woirata as is shown in Figure 1. There are four languages on Kisar Island: Meher, Woirata, Local Malay or Melayu Tenggara Jauh (MTJ), and Indonesian.

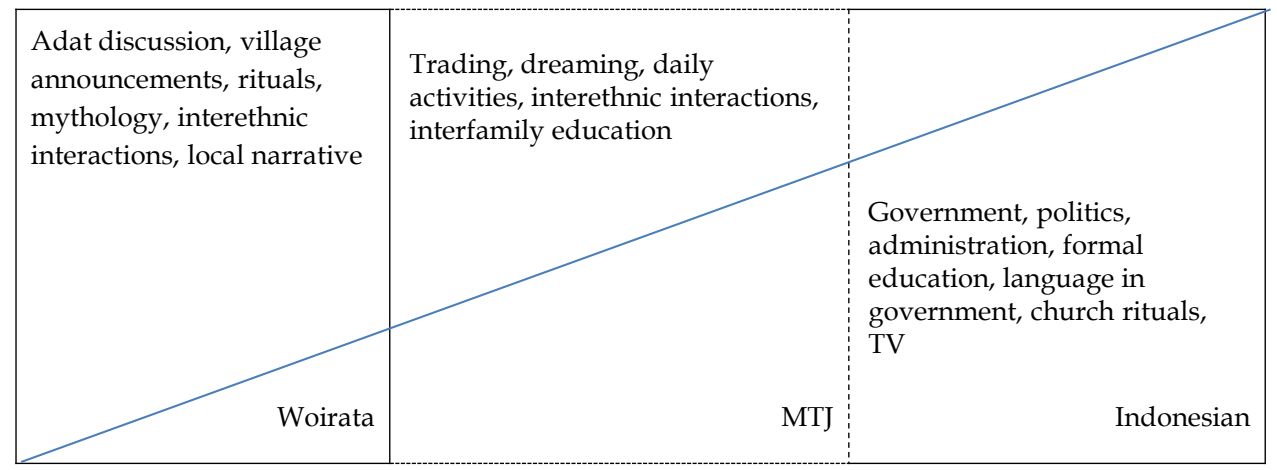

Figure 1. Language Use in Woirata after the colonial period (Nazarudin 2013: 61).

Figure 1 shows that there is a diglossic situation in Woirata. Indonesian is used as the national language and the only language of education. However, instead of formal Indonesian, Woirata speakers tend to use MTJ (Van Engelenhoven 2002) more often than Indonesian. Even though on the questionnaire they confirm to use Indonesian on a daily basis in their daily activities, the fact is that the type of "Indonesian" they use is rather MTJ, a local variant or dialect of Malay. Speakers under 30 years old use MTJ when they meet speakers from other languages and sometimes they also use MTJ at home when talking with their parents and other family members.

Figure 1 also shows that MTJ has been in use over a very wide area since the Dutch colonial period. However, Woirata speakers inform that their grandparents' generation used to be very fluent in Meher and used Meher as a lingua franca at that time (see Figure 2). Moreover, most of the traditional songs in Woirata were sung in Meher, because they wanted Meher people to understand their songs. In this colonial period, the songs were mostly about their ancestors as the real lords of the land.

\begin{tabular}{|l|l|}
\hline $\begin{array}{l}\text { Adat discussion, village } \\
\text { announcements, rituals, mythology, } \\
\text { interethnic interactions, daily activities, } \\
\text { dreaming }\end{array}$ & $\begin{array}{l}\text { Trading, interethnic interactions, } \\
\text { traditional songs, fishing on the sea }\end{array}$ \\
\hline \multicolumn{1}{|c|}{ Woirata } & Meher \\
\hline
\end{tabular}

Figure 2. Language use in Woirata before the colonial period.

In the early twentieth century, Malay had become more widely used under 
the Dutch colonial government and was succeeded by Indonesian after the Independence in 1945. As such, the current old generations (ages 60 - 80s) appear no longer able to speak Meher and prefer to use MTJ or Indonesian as their lingua franca. Since the Independence, Indonesian had become the national language throughout the country and moreover the government decided to use Indonesian as the only language for education. This policy had an effect on every local language in Indonesia, since all students were forbidden to use their local languages in school.

Since MTJ has become the lingua franca for both Woirata and Meher people, one may expect a deep language contact between all three languages in which MTJ has strongly influenced Woirata. This paper intends to describe the causative constructions in Woirata as a means to show the effect of this language contact scenario on the Woirata language.

\section{Causatives in Woirata}

Song (1996) defines a causative construction as a linguistic expression that denotes a complex situation consisting of two events: (1) the causing event in which a causer does something, and (2) the caused event in which a causee carries out an action or undergoes a change of condition or state as a result of the causer's action. Velupillai (2012) states that causative constructions essentially merge two separate events into one single complex event which in turn increases the valency of the original event by one. Causatives are commonly divided into three different types, lexical, morphological, and analytic. In lexical causatives the semantics of the verb itself contains a notion of causation. Morphological causatives on the other hand apply a separate morphological process on to the base verb in order to signal the notion of causation, whereas analytic causative constructions rather use a separate verb to get the notion of causation, as in English to make someone do something (Velupillai 2012: 260-264).

Typologically, the Woirata causative is an analytic construction that uses the verbs (e)me and pai. Both (e)me and pai function as auxiliaries. However, both may occur as independent verbs as well; (e)me with the meaning 'take', 'treat', 'bring' or 'give' and pai with the meaning 'make' or 'do'. For consistency both verbs will be glossed in the examples as 'take' and 'do', respectively. Both (e)me and pai are transitive, as is shown in the following examples.

(1) an=te ira me. (Woirata)

$1 \mathrm{SG}=\mathrm{SBJ} \quad$ water take

'I take water.'

(2) Ha-le, ina pai? (Woirata)

Father=EXCLA what do?

'What are you doing, Sir?' 
Woirata is a Subject-Object-Verb (SOV) language. Example (1) shows that the transitive verb me 'take' appears at the end of the sentence after the object noun ira 'water'. Similarly, pai 'do' appears after the interrogative pronoun object ina 'what'.

\subsection{CONSTRUCTIONS WITH (E)ME}

Woirata has one causative construction that contains the verb eme/me 'to bring/ take'. This verb profiles a transfer action. As can be seen from its English translation, the direction of the transfer is not implied in the semantics of the verb. An additional verb $m a^{\prime} u$ 'come' is required to mark the notion 'transfer towards the point of orientation' or mara 'go' to signal 'transfer away from the point of orientation'. The latter is exemplified in (3) below.

$$
\begin{aligned}
& \text { (3) ...le eme sere mara. } \\
& \text { con obj.take beach go } \\
& \text { '... and brought it to the beach.' (De Josselin de Jong 1937: 95) }
\end{aligned}
$$

The bisyllabic allomorph eme in the example above signals that its object has been mentioned in a preceding clause (indicated in the glosses by овJ). Example (4) displays this verb's monosyllabic counterpart me that encliticizes to an object argument.

$\begin{array}{cll}\text { (4) .. hihi } & \text { Yotowa } & \text { me... } \\ \text { Goat } & \text { Kisar } & \text { take }\end{array}$

'(Wurkeliau and Lolkeliau) took a sheep ...' (De Jossein de Jong 1937: 81)

In his discussion of 'take' in Woirata's co-gener Fataluku in nearby TimorLeste, Van Engelenhoven (2010b) observes that in certain phonotactic conditions this verb is evolving into a dative marker on nouns to which the object implying allomorph eme is added. Ongoing research suggests that also in Woirata objects are sometimes followed by eme rather than $m e .^{3}$ The principles behind this remain unclear for the time being and require further research.

The causative (e)me construction is extremely productive in Woirata. It contains two appositive clauses. The continuous line in example (5) is meant to show that the boxed object of me, hai 'pig', is co-referential with the subject of mudu-ume 'lay inside', which as such is deleted from its default slot (indicated by the boxed $\varnothing)$.

3 For example: Loi-loi tie eme natara mudu-ume (RED-proa take house in-lay) 'Put (= make lay) the motorcycle in the house.' 

(5)
An-te mara hai me $\varnothing$ kodo mudu-ume.
$1 \mathrm{SG}=\mathrm{SBJ}$ go pig take cage inside-lay
'I go put the pig in the cage.' (Woirata)

Examples (6) and (7) show that the Woirata construction closely resembles the 'give' construction in MTJ (Van Engelenhoven, this volume) and in Meher, notwithstanding the SVO word order of the latter two. This will be further elaborated in Section 4.

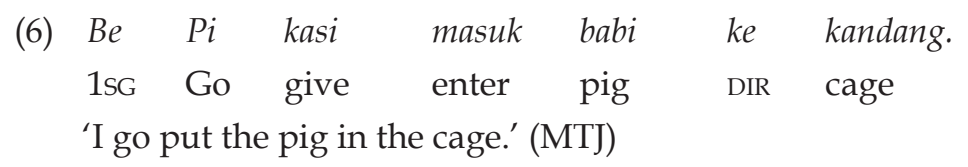

(7) Ya La '-al wawi la popa raran.
1sG Go 1sG-give pig go cage inside
'I go put the pig in the cage.' (Meher)

\subsection{CONSTRUCTIONS WITH PAI}

Whereas Woirata only features one (e)me construction, the corpus collected during fieldwork in 2013 shows four types of causative construction with pai 'do'. The first three appear to be copied after the general transitive construction with this verb, as exemplified in (8). Example (9) shows its counterpart in which the noun hala 'field' is combined with pai into an intransitive construction.
(8) An=te hala=na'a pai.
$1 \mathrm{sG}=\mathrm{SBJ} \quad$ field $=\mathrm{DEM}$ do
(9) An=te hala-pai.
$1 \mathrm{sG}=\mathrm{SBJ} \quad$ field-do
'Imake this garden.' (Woirata)
'I am farming.' (Woirata)

Example (10) displays the first type in which pai is preceded by another transitive verb, which is obligatorily nominalized. Interestingly, Faust (2006) does not mention this construction in her analysis of De Josselin de Jong (1937). Van Engelenhoven (2009b), however, does observe a similar construction in Fataluku.

$$
\begin{aligned}
& \text { (10) ...le eme na// ha ununa-n pai. } \\
& \text { then OBJ.take mother father eat.PL.NOM do } \\
& \text { '... and then (they) made their parents eat (it).' (Woirata) }
\end{aligned}
$$

The second type is little attested in modern Woirata. In this construction an intransitive verb combines with pai into what I consider to be a serial verb construction. This is exemplified in (11). Here, the noun ira 'water' obviously functions as the object of the intransitive - transitive serial verb combination 
$a r^{\prime}$ (to be) hot' plus pai 'do'. Also very few instances of this construction have been attested in De Josselin de Jong's (1937) data, of which one example is displayed in (12).

$$
\begin{aligned}
& \text { (11) ira } a r=p a i \\
& \text { water hot }=\text { do } \\
& \text { '... to heat water.' (Woirata) }
\end{aligned}
$$

$\begin{array}{ll}\text { Etu naware pai... } & \\ \text { then know do }\end{array}$

(De Josselin de Jong 1937: 84)

Van Engelenhoven (2010b) reports a process of initial consonant mutation in verbal compounds in Fataluku. Whereas in modern Woirata it no longer seems productive, De Josselin de Jong's (1937) data sometimes displays allomorphic variation among verb that resembles Fataluku consonant mutation. This is exemplified in (13) where 'to do' has an allomorphs hai instead of expected pai.

$$
\begin{aligned}
& \text { (13) ... to uma koune // kemene-n ti liar=hai... } \\
& \text { CON earth dark dark=NOM DEM transform=do } \\
& \text { '... so (God) changes the darkness of the earth ...' } \\
& \text { (De Josselin de Jong 1937: 70) }
\end{aligned}
$$

The third type of causative construction is far more frequent in my database and also attested by Faust (2006). Here, the intransitive verb follows rather than precedes pai. This is exemplified in (14) by the verbs titlene 'dry', and hatate 'dry'.

$$
\begin{aligned}
& \text { (14) ...pai titlene// pai hatate. } \\
& \text { do dry do dry } \\
& \text {... (to) dry it, to drain it.' (Woirata) }
\end{aligned}
$$

The square brackets in (15) shows that the nouns iyar 'road' and wati 'path' function here as objects to the intransitive verb-pai construction. Interestingly, this construction is absent in Fataluku. This will be further elaborated in Section 4 where I will analyse this construction as a grammatical calque from MTJ.

$$
\begin{aligned}
& \text { (15) ... iyar [pai mama'a]// wati [pai mama'a] to ... } \\
& \text { road do clean path do clean con } \\
& \ldots \text { (to) clean the road, to clean the path, and then ...' (Woirata) }
\end{aligned}
$$

Following Faust (2006) I analyse these structures as monoclausal multiverb constructions in which pai functions as an auxiliary verb that profiles causativity. In the following example, the boxed nominal compound wou-wou amu 'blowgun dart' is a left-dislocated object. The boxed $\varnothing$ indicates its default location in the clause where it functions as the object of pai. The continuous line 
between the latter and the boxed $\varnothing$ signals their mutual grammatical relation, whereas the dashed line signals the semantic relation between the referent of the boxed 'blowgun dart' and the verb mule 'disappear', that functions as a topic constituent preceding the subject anu '1sG'.

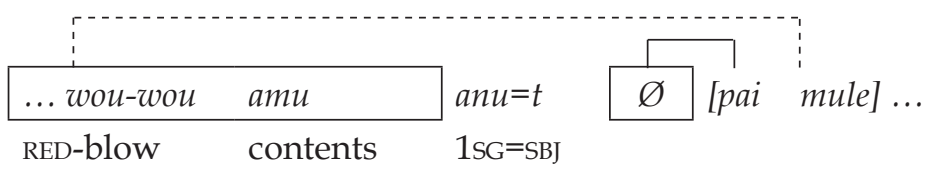

... the blowgun arrow that I made disappear ...' (De Josselin de Jong 1937: 89)

Example (17) displays the fourth type of causative pai construction that was attested by Faust (2006: 40). This is a biclausal construction in which a pai clause is conjoined to a consecutive clause by means of to 'SEQ'. ${ }^{4} \mathrm{Van}$ Engelenhoven (this volume) explains this 'sequential coordination' as he labels it as a typical feature of Luangic languages and MTJ in which the order of the clauses signals the chronological order of the events they refer to. Whereas the co-coordinative character of this clause combination may appear obvious in Luangic, the Woirata case, however, suggests as more interdependent relation between both clauses. Example (17) in fact is a vetative construction in which the prohibitive clitic toho is added after the second singular subject $a$, while in sentence-final position, at the end of the second clause the negator clitic is added. The grammatical relation between the boxed object $e=h e l e$ your friend' and pai is indicated by a continuous line. The dashed line hints at the semantic relation between the object's referent in the first clause and the verb umu 'die' in the final clause.

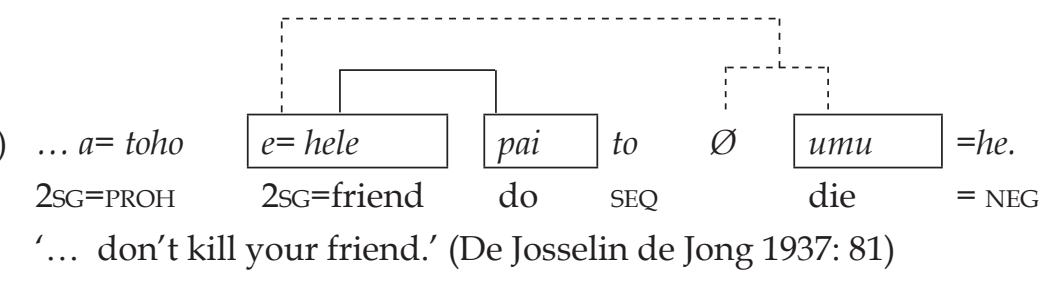

In these pai to constructions the causer is always an animate entity, which imposes an intentional reading of the profiled actions.

\section{Causative constructions in MEHER And MELAyU TENGgarA JAUH}

In order to better appreciate the causative constructions in Woirata discussed in Section 2, a brief comparison with Meher and MTJ is in order. No data whatsoever, however, on Meher causatives has been published yet, whereas work on MTJ is thus far confined to Van Engelenhoven (2002 and in this volume). 
In the first mentioned paper, Van Engelenhoven focuses on 'give' constructions and concludes that inanimate objects always require a multiverb construction of kasi 'give' and for example an intransitive verb as turun 'descend', as shown in example (18). This construction signals that the object has no control over the action profiled in the clause and can also be used for animate objects as in example (19). Animate objects may also occur in a biclausal combination in which the object of kasi functions simultaneously as the subject of the following verb. This construction indicates that the referent of the object/subject can control the profiled action. This is exemplified in (20).

$\begin{array}{llll}\text { (18) Dia } & k^{5} s^{5} & \text { turun } & \text { layar. } \\ \text { 3sG } & \text { give } & \text { descend sail }\end{array}$

'He lowers the sail.' (Van Engelenhoven 2002: 185)

$\begin{array}{lllll}\text { (19) Dia kas turun } & \text { nara. } & \text { (20) } & \text { Dia kas nara turun. } \\ \text { 3sG give descend sister } & \text { 3sG give sister descend } \\ \text { 'He lowers you.' } & & \text { 'He has you get down.' } \\ \text { (Van Engelenhoven 2002: 185) } & \text { (Van Engelenhoven 2002: 186) }\end{array}$

In this volume Van Engelenhoven elaborates also on the 'make' or 'do' construction. Here, instead of focusing on the semantic role of the grammatical object, he elaborates on the influence of the causer of the profiled event. Like the 'give' construction the 'do' constructions distinguishes a multiverb combination and a biclausal combination respectively signal maximal and minimal involvement of the causer in the profiled events. This is exemplified in (21) and (22).

$\begin{array}{llll}\text { (21) Nakoda bikin tenggelam } & \text { kapal. } \\ \text { Captain do sink } & \text { ship }\end{array}$

'The captain sank the ship.' (Van Engelenhoven 2015 in this volume)

$\begin{array}{lllll}\text { (22) Nakoda bikin } & \text { la kapal tenggelam. } \\ \text { captain } & \text { do } & \text { CON ship sink }\end{array}$

'The captain made the ship sink.' (Van Engelenhoven 2015 in this volume)

Meher differs slightly from Woirata and MTJ. In Meher, there are also two causative markers, $h i^{\prime} i$ 'make' and -ala 'take'. Since its stem has an initial vowel, the latter requires inflection with a pronominal subject marker (Blood 1992). In his unpublished work, J. Christensen and S. Christensen (1992) stress the 'verbiness' of -ala. However, since the final / a/ is always deleted in this specific causative construction, this verb seems to become a prefix rather than 
an independent verb, comparable to what Van Minde (1997) observed for kasi 'give' in Ambonese Malay. This is exemplified in (23).

$$
\begin{aligned}
& \text { (23) Ai } n \text {-al=kopur walar. } \\
& \text { 3sg } \quad \text { 3sG.take=descend sail } \\
& \text { 'He lowers the sail.' (Meher) }
\end{aligned}
$$

Meher appears only to have multiverb 'take' constructions and as such differs significantly from MTJ that has two different types. Example (24) shows that it rather resembles the Woirata 'take' construction discussed in 2.1, albeit that the latter actually is a biclausal appositive construction in which the final subject has been coreferentially deleted.
(24)
$\begin{array}{lll}\text { Ue } & \text { leher } & m e=h o u t e . \\ \text { 3sG } & \text { sail } & \text { take=descend }\end{array}$
'He lowers the sail.' (Woirata)

Similarly, $h i^{\prime} i$ 'do' constructions are always multiverb combinations, as exemplified in (27). Note that the pronominal prefix here phonologically docks as a coda on the vowel nucleus of the preceding pronoun.

$$
\begin{aligned}
& \text { (25) Hi=r-hi'i yak-edi au hanan. } \\
& \text { 3PL=3PL. do bad.TAM wood branch } \\
& \text { 'They ruined the branch of the tree.' (Meher) }
\end{aligned}
$$

\section{CONCLUSION}

De Josselin De Jong's (1937) text was principally meant as a contribution to the anthropology of the region. He conducted fieldwork among members of the Hano'o clan for five weeks during which he recorded an origin myth. In the introduction of his book De Josselin de Jong describes how the narration was recorded. With the assistance of a native interpreter he wrote down several minutes of narration, after which the informant was asked to continue for another few minutes, which were then again written down after the informants was asked to stop again. No audio recordings exist of these sessions held, but even if they existed they would have been of little use, since the text in De Josselin de Jong hardly can hardly pass for natural speech.

Faust (2006) was the first thorough attempt to analyze this text. She found three different analytic causative constructions in Woirata: pai + intransitive verb, pai to, and (e)me + transitive or intransitive verb. Faust (2006: 39) interprets the enigmatic pai + intransitive verb as meaning 'make X happen'. Faust's (2006) analysis about the Woirata causative constructions seems either incomplete or limited. This is mainly due to the fact that it exclusively is based on data from De Josselin De Jong (1937). Whereas she concludes that causative 
pai can only occur before intransitive verbs, ongoing research reveals that it can occur before both transitive and intransitive verbs.

Table 1 shows that whereas the 1937 data and present-day data display significant differences in pai constructions, the (e)me construction has not changed.

\begin{tabular}{|l|l|l|}
\hline $\begin{array}{l}\text { Causative } \\
\text { construction }\end{array}$ & $\begin{array}{l}\text { De Josselin de Jong } \\
(1937)\end{array}$ & Woirata 2015 \\
\hline 'do' construction & VINTR + pai & VINTR + pai \\
& $p a i+$ VINTR & $p a i+$ VINTR \\
& - & $p a i+$ VTR \\
& - & VTR.NOM $+p a i$ \\
& $p a i$ to VINTR/TR & - \\
\hline 'take' construction & $(e) m e+(\mathrm{N}+)$ VINTR/TR & $(e) m e+(\mathrm{N}+)$ VINTR/TR \\
\hline
\end{tabular}

Tabel 1. Woirata causative constructions compared.

Woirata is a genetic outsider when compared to its fellow languages Meher and MTJ on Kisar Island. This is mainly visible in its SOV word order, whereas both Austronesian languages display an SVO order. A closer look at its causative constructions, however, shows that all three languages are very similar and use the same lexical items as causative verbs. These are reiterated in Table 2.

\begin{tabular}{|l|l|l|l|}
\hline Gloss & MTJ & Meher & Woirata \\
\hline 'do' & bikin & hi'i & pai hai \\
\hline 'take' & kasi & - al(a) & me \\
\hline
\end{tabular}

Table 2. Causative verbs in MTJ, Meher, and Woirata.

These facts connect to Figure 1 at the beginning of this paper. It sketches a language use situation on Kisar Island that implies deep language contact, which inevitably has caused the Woirata language to divert from its 1937 condition, even though its exclusive word order has remained unchanged.

In Tutuala (Timor-Leste) a comparable intensive language contact between Makuva and Fataluku situation exactly induced Makuva to change from SVO to SOV (Van Engelenhoven 2010a). Except for the word order, almost every aspect in the Woirata language appears to have shifted away from the blueprint as displayed by its co-gener Fataluku. Probably it is this adaptation quality that may explain why this extremely small and endangered language has managed to survive in between its aggressive neighbor languages. 


\section{SYMBOLS USED}

$=\quad$ clitic boundary with final vowel apocope or internal metathesis in the leftside morpheme

- $\quad$ morpheme boundary with final vowel apocope or internal metathesis in the leftside morpheme

// lexical parallelism

- combined meanings without morpheme boundary

$\varnothing \quad$ co-referential which is deleted from its default slot.

glottal sound

\section{ABBREVIATIONS USED}

2

3

first person singular

second person singular

third person singular

$\mathrm{CON}$

conjunction

DEM

demonstrative

DIR

directional clitic

EXCLA exclamation marker

MTJ Melayu Tenggara Jauh

$\mathrm{N}$ noun

NEG negation marker

NOM nominalization suffix

OBJ object

PL plural

$\mathrm{PROH} \quad$ prohibitive marker

RED reduplication

SEQ sequential coordination marker

SG singular

SOV Subject-Object-Verb word order

SBJ subject

SVO Subject-Verb-Object word order

TAP Timor-Alor-Pantar language family

TAM Tense-Aspect-Mood marker

$\mathrm{V} \quad$ verb

VINTR intransitive verb

VTR transitive verb

\section{REFERENCES}

Blood, Cindy. 1992. "Subject-Verb Agreement in Kisar", NUSA; Linguistic

Studies of Indonesian and Other Languages in Indonesia 34: 1-20. 
Christensen, John and Sylvia Christensen. 1992. "Kisar Phonology”, in: Donald A. Burquest and Wyn D. Laidig (eds), Phonological studies in four languages of Maluku, pp. 33-65. Dallas TX: The Summer Institute of Linguistics, University of Texas at Arlington, and Pattimura University.

Engelenhoven, Aone van. 2002. "Verb sequences in Melayu Tenggara Jauh; The interface of Malay and the indigenous languages of Southwest Maluku", in: K.A. Adelaar and R.A. Blust (eds), Between worlds; Linguistic papers in memory of David John Prentice, pp. 177-191. Canberra: Research School of Pacific and Asian Studies, Australian National University. [Pacific Linguistics 529.]

Engelenhoven, Aone van. 2009a. "The position of Makuva among the Austronesian languages of East Timor and Southwest Maluku", in: K. Alexander Adelaar and Andrew Pawley (eds), Austronesian historical linguistics and culture history; A festschrift for Bob Blust, pp. 425-441. Canberra: Research School of Pacific and Asian Studies, Australian National University. [Pacific Linguistics 601.]

Engelenhoven, Aone van. 2009b. "On derivational processes in Fataluku, a non-Austronesian language in East-Timor", in: W. Leo Wetzels (ed.), The linguistics of endangered languages, contributions to morphology and morphosyntax, pp. 331-362. Utrecht: Netherlands Graduate School of Linguistics. [Occasional Series 13.]

Engelenhoven, Aone van. 2010a. “The Makuva enigma; Locating a hidden language in East Timor", Revue Roumaine de Linguistique/Romanian Review of Linguistics 80(2): 141-161.

Engelenhoven, Aone van. 2010b. "Verb serialisation in Fataluku; The case of 'take'", in: Sascha Völlmin, Azeb Amha, Christian J. Rapold, and Ch. Zaug- Coretti (eds), Converbs, medial verbs, clause chaining and related Issues, pp. 185-211. Köln: Köppe Verlag.

Engelenhoven, Aone van. 2015. "Kasi and bikin; Two causative strategies in Melayu Tenggara Jauh (Southwest Maluku, Indonesia)”. [In this volume.] Faust, Vera. 2006. "Woirata, a language of Kisar; 1. Grammatical sketch, 2. Myth of creation" (glossed text). MA thesis, Leiden University.

Grenoble, Lenore A. 2011. "Language ecology and endangerment", in: Peter K. Austin and Julia Sallabank (eds), The Cambridge Handbook of Endangered Languages, pp. 27-44. New York: Cambridge University Press.

Josselin de Jong, J.P.B. de. 1937. Studies in Indonesian Culture; I. Oirata, a Timorese settlement on Kisar. Amsterdam: Noord-Hollandsche uitgeversmaatschappij.

Lewis, M. Paul, Gary F. Simons, and Charles D. Fennig (eds). 2014. Ethnologue; Languages of the World. Seventeenth edition. Dallas, TX: SIL International.

Minde, Donald van. 1997. Malayu Ambon; Phonology, morphology, syntax. Leiden: Research School CNWS.

Nazarudin. 2013. "Revitalisasi bahasa Oirata berbasis masyarakat", in: Soewarsono, Leolita Masnun, dan Nazarudin, Revitalisasi Budaya dan Bahasa Oirata, pp. 57-91. Jakarta: LIPI dan PT Gading Inti Prima. 
Schapper, Antoinette, Juliette Huber, and Aone van Engelenhoven. 2012. "The historical relations of the Papuan Languages of Timor and Kisar", Language and Linguistics in Melanesia: 194-242.

Song, Jae Jung. 1996. Causative and causation; A universal typological perspectives. London: Longman.

Taber, Mark. 1993. "Toward a better understanding of the indigenous languages of Southwestern Maluku", Oceanic Linguistics 32/2: 389-441.

Velupillai, Viveka. 2012. An introduction to linguistic typology. Amsterdam: John Benjamins. 